\title{
DETERMINANTS OF STATE REGULATION OF THE COMPETITIVENESS OF MODERN NATIONAL ECONOMIES
}

\author{
Oksana Redkva', Olha Haran², Liudmyla Prystupa ${ }^{3}$
}

\begin{abstract}
The purpose of the article is to develop and systematize the theoretical foundations of state regulation of economic competition in Ukraine and to identify the priority vectors for the implementation of the national competition policy. Methodology. In the given work, the questions of the state regulation of economic competition in the national economy of Ukraine are considered through the prism of the indication of the purpose and role of state regulation in this area; through the definition of the system of participants in the competitive environment; through the factors that focused the competitive struggle between domestic producers are noted. Results. Our analysis allows us to assert that the leading role in the functioning of a healthy competitive environment belongs to a state that is able to create all the necessary preconditions for its proper development of competition in a rational economy and to ensure stable positions of economic entities by its economic and legal instruments. The development and improvement of the institutional and legal frameworkfor the regulation of competition increase the competitiveness of the national economy. Practical implications. In the case, when the competition, regulated by law, achieves a balance between supply and demand, and ultimately between social needs and production. Its role is to provide an optimal balance of interests, prevent the acquisition of super-profits by business entities and ensure the standard level of goods' quality and the necessary volumes of commodity content of the market. Under such conditions, the competitive activity of state bodies is aimed to create and develop a competitive environment, protecting competition, antimonopoly regulation in order to increase the competitiveness of economic entities, stimulating the efficiency of production, better meeting the needs of the consumer. Value/originality. The obtained theoretical and practical results illustrate the state of state regulation of economic competition in Ukraine, which allows predicting the main directions of improvement of mechanisms of influence on the competitive environment of the national economy.
\end{abstract}

Key words: economic competition, state regulation, economy, competitive environment.

JEL Classification: D19, D41

\section{Introduction}

The competitive environment is a prerequisite for the existence of the economy, and the creation of a competitive mechanism for the functioning of the economic system is a priority task of reforms that will facilitate the creation of conditions for the implementation of progressive market transformations. Therefore, without a doubt, competition research is relevant. Economic and political realities, as well as a weak movement with reform in Ukraine, reinforce the urgency of the study. For example, according to the State Statistics Service of Ukraine, the consumer inflation rate in 2017 increased and amounted to $13.7 \%$.

The current state of the national economy requires continuous improvement of the forms and means of the state regulatory influence on the relations of competition, the search for criteria to establish the boundaries of state-legal interference in the sphere of competition. Although the economic situation in the country remains complicated, and post-crisis stabilization is occurring too slowly, however, in 2015-2017, the first signs of restoration of economic activity in the domestic markets of Ukraine appeared.

Thus, it is necessary to understand the role of the state in the processes of ensuring the formation of a competitive environment, the content of state regulation of competition relations and, most importantly, to solve the key issue of the development of domestic competition law, which is related to the definition of competition as a whole or as a means of

\footnotetext{
Corresponding author:

${ }^{1}$ Ternopil Ivan Puliui National Technical University, Ukraine.

E-mail: oksanaredkva@ukr.net

${ }^{2}$ Odessa Institute of Trade and Economics of Kyiv National University of Trade and Economics, Ukraine.

E-mail: olgast@bigmir.net

${ }^{3}$ Khmelnytskyi National University, Ukraine.

E-mail: olgprystupala@gmail.com
} 
building a highly efficient economy. The need to resolve the issue is compounded by the fact that the necessary investments, but a pathetic situation has been created. On the one hand, low labour costs in Ukraine, and therefore, the possibility of obtaining a cheaper product to generate more profits in the future, but the realities of today are unsafe business, since the rules of the game for business are not very transparent, given the high level of corruption and weak protection of private property, reduce the volume of investment activity.

It is obligatory to take into account the state of regulation of economic competition: the labour crisis in Ukraine that is due to certain factors, which include labour migration abroad for skilled workers; emigration of Ukrainians who go abroad for study, etc. For example, according to a study by Expat Insider, at the end of 2017, about 1.2 million Ukrainians already work in Poland, but according to domestic demographers, this figure is at least half a million; the share of the export sector remains insignificant. For example, in 2017, exports from Ukraine to the EU grew by $27 \%$, while import volumes from the EU to Ukraine increased by $22 \%$, with total trade increased by $24 \%$. In 2018 , the volume of trade between the EU and Ukraine continues to grow; national households provide up to $68 \%$ of GDP (gross domestic product) of a country; insufficiency of investment resources. For example, in 2016, Ukraine's rating for the "Innovation" group improved to 52nd place versus 54th in 2015, and in 2017 - it fell in the ranking of 61st place (Report MICU).

Also, the necessity of rethinking the influence of state regulation on economic competition was influenced by the Law of Ukraine "On Government Aid to Business Entities” dated July 1, 2014, № 1555-VII, which entered into force in full as of August 2, 2017. The Law of Ukraine № 1555-VII introduced new mechanisms that have a significant impact on competition, a new type of relationship between the state and business entities.

\section{Analysis of recent research and publications}

Various issues of economic competition as a socioeconomic phenomenon are investigated in the works of G. Azoyev (1996). A. Smith and D. Ricardo noted that competition is a contest for profit (Smith, 2001).

In the scientific works ofI.Ansoffand M. Porter(1993), the theoretical basis for understanding the concepts of "competition", "competitiveness", "competitive advantages", their interconnection and influence on the processes of planning and strategic management of the enterprise are laid. M. Porter's works detail the international competition as an economic category, its forms and ways of improvement (Porter, 1993). J. Schumpeter (1982), having determined that perfect competition for society is an incentive for minimizing costs and maximum approximation of wages to its marginal productivity, carried out judicial contribution to the development of the theory of competition. Effective competition, according to Schumpeter, is possible only under conditions of economic dynamics. This condition is ensured by a qualitatively new level of production, based on the continuous introduction of innovations, innovation at all levels of technology, management and organization of production, product quality, development of new markets, raw materials. That is, effective competition is a new type of competition, built on innovation (Schumpeter, 1982).

A remarkable event on this issue was the publication of N. Korchak's monograph that describes the economic and legal aspects of state regulation of competition in Ukraine and states that the laws of the market mechanism create an objective boundary for the state's intervention in the economy as a whole (Korchak, 2014).

Yu. Rosetska investigated the state of the competitive environment in Ukraine. The author outlines the main institutional barriers hindering the free movement of capital in the interbranch and intersectors. The ways of overcoming the institutional constraints of competition in the Ukrainian economy, taking into account the trajectory of the previous development, existing multigeneration, the realization of the interests of the groups of institutional innovators, the reform of the system of branch, regional and horizontal state aid to the branches of industry (Rosetska, 2008), are outlined.

O. Maslak (2014) investigated the essence and competitions' forms and formulated an author's view of its role in the modern economic system. The author highlighted the most characteristic features of modern globalization processes and grounded the need for the development of methodological provisions and practical recommendations for the formation of a mechanism for increasing the competitive opportunities and advantages of industry in the domestic and foreign markets (Maslak, Kvyatkovskaya \& Kulinichev, 2014).

But, despite a large number of scientific studies in this area, the issue of state regulation of competition in the national economy does not lose its relevance and, therefore, needs further research taking into account the present realities.

The purpose of the study is to develop and systematize the theoretical foundations of state regulation of economic competition in Ukraine and to determine the priority vectors of the implementation of competition policy in Ukraine.

\section{Analysis of the general theoretical principles of state regulation in the field of economic competition in Ukraine}

In modern conditions, the value of competition is increasing, due to its role in the economy as the main "engine" of the functioning of the market mechanism. Competition is one of the economic means of struggle for the consumer and the emergence of an effective 
owner is the subject of management. Competitive struggle between domestic producers is intensified under the influence of such factors as: reduction of domestic solvent demand due to lower real incomes; difficult business conditions, due to the rupture of trade relations with partners, the increase in production costs through devaluation processes etc., remain constraining factors for increasing competitive advantages. Thus, sometimes contributes to the use of unfair methods of competitive struggle. Moreover, in such periods of crisis economic recovery, the role of the Antimonopoly Committee of Ukraine as a guarantor of the protection of fair competition increases.

Therefore, the implementation of state regulation in the field of economic competition is due to the need to balance the interests of business entities and consumers. From the point of view of harmonization of the opposing interests of commodity producers during the competitive struggle, the internal forces of the progressive vector of development accumulate among the participants of the competitive environment. A dynamic character characterizes competitive relations. They are transformed under the influence of changes associated with globalization, uneven development, and the intensification of competition between countries, regions, and market participants. Therefore, the state in the process of competition should ensure the efficiency of business entities by creating conditions for such activities and protect the interests of consumers from violations of rules and other unlawful actions of business entities aimed at unlawful redistribution of material goods from consumers and conscientious subjects to unscrupulous.

Given the need for the state to coordinate the interests of all participants in economic relations, there is a need to clearly determine their composition. Participants in relations in the field of economic competition may include: a) producers of products, goods, works, services; b) consumers of products, goods, works, services; c) persons regulating the relations in the field of competition. When the question of the right regulation of economic competition is investigated, it is impossible to ignore the attention of those who regulate relations in the field of competition. These individuals, depending on what interests they are meeting, can be divided into two large groups:

a) Persons acting in order to maintain a competitive environment prevent and non-admittance of negative manifestations of competition and monopoly. As a rule, these are authorized state bodies, which have the appropriate competence in the field of economic competition. Such persons, in most cases, act in the interests of the state and society.

b) Persons who, by virtue of certain circumstances, have the opportunity to influence other market participants and consumers by establishing their conditions of access to the market of products, goods, services, works or their implementation. This group of individual acts in their own interests, harming other participants, therefore, they are subject to certain restrictions to reduce the level of harm.

The need to focus on individual who regulate relations in the field of competition has not only scientific interest but also a practical one. Thus, the group of persons acting in order to maintain a competitive environment, the prevention and non-admittance of negative manifestations of competition and monopoly are regulators, controlling the authorities and acting in the manner prescribed by law and within its competence, that is, as a rule, authorized bodies or authorities to which powers are delegated. The bright representatives of this group are the Antimonopoly Committee (hereinafter AMCU), the Ministry of Energy and Coal Industry of Ukraine, and others.

The second group is individuals who, due to certain circumstances, have the opportunity to influence other market participants and consumers by establishing their access conditions to the market of products, goods, services, works or their implementation. Representatives of this group are potential (or real) violators of competition law. This group may include natural monopolies, "major players" in a particular market. For example, the largest importers of liquefied petroleum gas in 2017 were, in particular, LLC GLUSCO Ukraine, LLC AVANTAZH 7, OPC “OKKO Naftoprodukt”, LLC "Import Trans Service”. LLC "Factoring Group”, LLC "AZ Supply”, LLC “NADEZHDA”, TOV “GAZTRON TRADE”, LLC “PROPAN TRADE”, LLC “SVG PLUS”, Eurostandart-Avtohaz TOV (Annual report of the Antimonopoly Committee for 2017, 2018).

State represented by authorized bodies ensures the creation of a competitive environment and the maintenance of a certain economic order, protects of economic competition through the performance of control functions in the field of regulatory and legal support and the economy when the perpetrators to violate the rules of economic competition to responsibility are made responsible.

State regulation of economic competition is provided through a system of measures carried out by the competent authorities aimed at preventing unfair competition and monopolistic abuses, their elimination and application of measures of liability to violators established by the state rules in the field of economic competition.

The legal basis of competition as an object of state regulation is characterized not only by legal instruments but also by analysis of regulatory policies and organizational and economic means. Legal means include the adoption of regulatory acts on the rules of conduct of management bodies and economic entities in the economic sphere. One of the main tasks of state regulation is the development of competition, but not its inhibition. 
The reason for state regulation of competition is the presence of state failures, monopolies, and other signs that require the state to intervene in supporting a significant level of competitiveness and protect the legitimate interests of all sectors. That is, the general goal of state regulation is the creation of effective competitive relations through the implementation in practice of the desired behaviour's model of the participants in these relations through the means of state influence.

The definition of a behavioural pattern is primarily due to the state regulation of economic competition, which is to ensure the functioning of the economy through the development of competitive relations and the introduction of integrity in competition.

This goal is realized through the tasks that determine the vectors of state influence on the economic environment. In addition, thus, the main directions of the implementation of state regulation in the field of economic competition are:

- protection of consumers' rights, which in most cases are more economically weak in comparison with other participants in market relations;

- stimulation of the competition development between commodity producers for consumers and, as a result, improvement of production and sale of goods, services, works; expansion of their assortment; improvement of quality; price optimization, etc. In other words, ensuring freedom of competition.

State regulation of economic processes is an important sphere for the domestic economy, and raising its competitiveness is one of the ways of Ukraine's exit on the trajectory of sustainable development (Shishka, \& Dzhumageldiev, 2015).

Therefore, due to legal instruments of influence on economic competition, as well as the structure, functions of legal principles of state regulation of economic competition, their interaction, and interconnectivity lead not only to protect economic competition but also contribute to the functioning of a modern market economy.

\section{Analysis of the problems of understanding and using the category of "economic competition" as an object of state regulation}

The objectivity of competitive relations is caused by: - firstly, the plurality of various forms and types of property, presented at a certain period of time in a given society;

- secondly, objectively existing competitive environment, which ideally creates a situation on the market of a certain product, when none of the participants can influence the decision of others;

- thirdly, the diverse interests of the entities of existing forms and types of property.

Considering that competition is an indispensable component of the market system and the main driving force for its effective development. The scientific understanding of these categories is extremely important in the context of the need to find new effective measures, tools, and methods that can be used by the state to regulate competitive relations.

Indeed, competition can stimulate the manufacturer and direct its economic interest in optimizing costs; a search of new markets for goods, services, works; the application of the latest technologies; improving the quality of goods, services, works, etc., in order to profit.

Economic competition reflects the relationship between business entities that manifest themselves in the struggle for the most favourable conditions for capital investment, resulting in the formation of different market models, and meet the needs of both society and individual consumers.

In modern conditions, experts perform different approaches to the definition of competition. Analysing the scientific literature and legislation of Ukraine, it is possible to state that there is no single point of view regarding the understanding of the concept of "economic competition". This polemic has not only theoretical but also practical value. The research of scientific views on the concept and essence of competition testifies to their multidimensionality and scope. In each case, many factors contribute to the content of this category and the formation of the concept, in particular, the historical use of the term tasks affected by the state of the economy and the determined vector of its development, etc.

However, all researchers point out unanimously, although there are no coordinated approaches to understanding the essence of economic competition, which is a necessary factor in the dynamic development of society since it forms economic freedom. The scientific certainty of the category "economic competition" will contribute to the reappraisal and improvement of approaches to performing business, to intensify and revitalize the private initiative, to stimulate the development of production and the efficient use of scarce resources, to promote the competitiveness of the national economy and achieve high rates of economic growth.

Consequently, competition dictates technological discipline, requires high-quality products, modern design, the ability to anticipate prospective needs, and not just trade that is produced and is still in demand. Economic competition as an object of state regulation is a complex phenomenon, which is constantly changing under the influence of many factors, including globalization processes. Today's requirements are taken into account when forming the concept of "economic competition" there is the need for a harmonious combination of social, natural, and the economic priorities' development of subjects of the globalized space.

Through the combination of social and market objectives, the situation is ensured when social 
indicators are achieved at the expense of the economy and vice versa, revealing the essence of socially oriented competitive relationships (Osinskaya, 2009). The issue of social responsibility is closely linked to the concept of sustainable economic development, which depends on the level of innovation in economic activity, creates the prerequisites for environmental protection and the effective use of natural resource potential, that is, contributes to solving socio-economic problems of society. An important factor that influences the definition of the essence of the category "economic competition" is the understanding that this economic phenomenon has a dualistic character.

A clear understanding of the concept of "economic competition" allows more efficiently carrying out state regulation of competitive relations, taking into account the peculiarities of the participants in these relations, defining the factors of competition while developing new methods and strategies for its conduct. It is necessary to emphasize the fact that in recent times, the urgent need to change the conceptual approach to understanding the state influence on competitive relations; this is due to the transformation of the competitive environment in the context of the development of globalization processes.

\section{Analysis of state regulation of economic competition in Ukraine}

State regulation is ensured through a system of measures that are used by a person authorized by the state to create an effective competitive environment.

The system of state regulation of economic competition in Ukraine includes four main components. Among them, there are legal regulation; granting of permits for economic competition and concerted actions; control over the state of the competitive environment; application to violators of sanctions.

The first part of the state regulatory system of the competitive environment is an arrangement of legal regulation; it creates the basis for the implementation of other state regulations' components and defines the "rules of the game" in a competitive environment. For example, the current legislation amended the order of control over concentrations and settlement actions. The purpose of these changes is to prevent the granting of permits for the concentration of economic entities with the participation of persons subject to sanctions at different stages of consideration of applications and concentration cases in order to prevent the actual legitimization of acquisitions and mergers. Mentioned actions are performed with the participation of subowners in the Law of Ukraine "On Amendments to some laws of Ukraine on protection of economic competition and improvement of control procedures for concentration of economic entities" dated on 21.09.2017, № 2195-VIII, amendments to the Law of
Ukraine "On Protection of Economic Competition" and the Law of Ukraine "On Sanctions".

According to the Law of Ukraine No. 2195-VIII as of 09.11.2017, the concentration permit is not granted if the actions for which such an authorization is required by the bodies of the Antimonopoly Committee of Ukraine are subject to special economic and other restrictive measures (sanctions) provided in Part 1 of Article 4 of the Law of Ukraine "On the Number of Applications for Granting Authorization for the Concentration of Entities Considered by the Antimonopoly Committee of Ukraine".

The second important element of the system of economic competition's state regulation is the granting of permits for economic competition and concerted actions, approval of documents and agreements that mediate these relations.

For example, the most popular market among the AMCUs is the market for agricultural products, which is $25.7 \%$ ( 155 permits) of the total share of granted permits, as well as machinery and instrumentation markets, which is $14.6 \%$ ( 88 permits) and construction, real estate and construction materials markets, which is 13.3\% (52 permits) (Annual report, 2017).

A special place among the system of permits is occupied by permits for the concentration of economic entities, such as the purchase of shares (parts) $-81.4 \%$ of the total; permits to acquire control in other forms $-14 \%$, and permits to jointly create a business entity $-3.3 \%$.

Control over the state of the market and compliance of its members with the established rules for ensuring economic competition in order to prevent offenses the third important element of the system of economic competition's state regulation. For example, in 2017, the AMCU suspended 256 violations of the Law of Ukraine "On Protection against Unfair Competition". Of these, there are 81 violations in the form of unfair competition, in respect of which the Committee made a decision on imposition of penalties, and 175 are actions containing signs of such violations, which were terminated in accordance with the recommendations provided by the bodies of the Committee to the subjects of management.

The fourth element of the system of state regulation of economic competition is the application to violators of sanctions.

The system of such sanctions are penalties; asset blocking; prohibition of participation in privatization, lease of state property by residents of a foreign state and persons who are directly or indirectly controlled by the residents of a foreign state or act in their interests; a total or partial prohibition on the implementation of transactions in securities issued by persons who are subject to sanctions under the Law of Ukraine "On Sanctions" dated August 14, 2014, No. 1644-VII.

The imposition of certain sanctions, in accordance with the legislation on the protection of economic 
competition, is fixed on the website of the Antimonopoly Committee in the section "Monitoring of concentrations and concerted actions" and increases control over the concentration of economic entities with the participation of persons subject to sanctions and others.

The application of a sanction involves obtaining a certain result. Thus, the size of the economic effect as a result of taking measures to terminate violations of the legislation on the protection of economic competition, in particular, the prevention of unlawful losses and expenses of legal entities and individuals, in 2017 amounted to 2561.0 million UAH, which is almost 1.8 times (by 79.1\%) more than in 2016 (1 425.1 million $\mathrm{UAH})$. In addition, the total amount of penalties imposed in 2017 amounted to 1803.2 million $\mathrm{UAH}$ (Annual report, 2017).

The composition of the basic offenses in the competitive environment has the following form: violation in the form of abuse of a monopoly position; violation in the form of anticompetitive concerted actions of business entities; violation in the form of unfair competition; violation of other species (Table 1). The largest share in the imposed sanctions is taken by violations in the form of anticompetitive concerted actions of business entities - more than 1684.6 million UAH.

\section{Table 1}

The structure of offenses and the size of sanctions imposed on them in 2017 in Ukraine

\begin{tabular}{|l|l|}
\hline \multicolumn{1}{|c|}{ Type of offense } & The size of the sanctions \\
\hline $\begin{array}{l}\text { violation in the form of abuse } \\
\text { of a monopoly position }\end{array}$ & almost 41.0 million UAH \\
\hline $\begin{array}{l}\text { violation in the form of anticompetitive } \\
\text { concerted actions of business entities }\end{array}$ & 1684.6 million UAH \\
\hline violation of unfair competition & almost 50.5 million UAH \\
\hline violation of other types & almost 27.2 million UAH \\
\hline
\end{tabular}

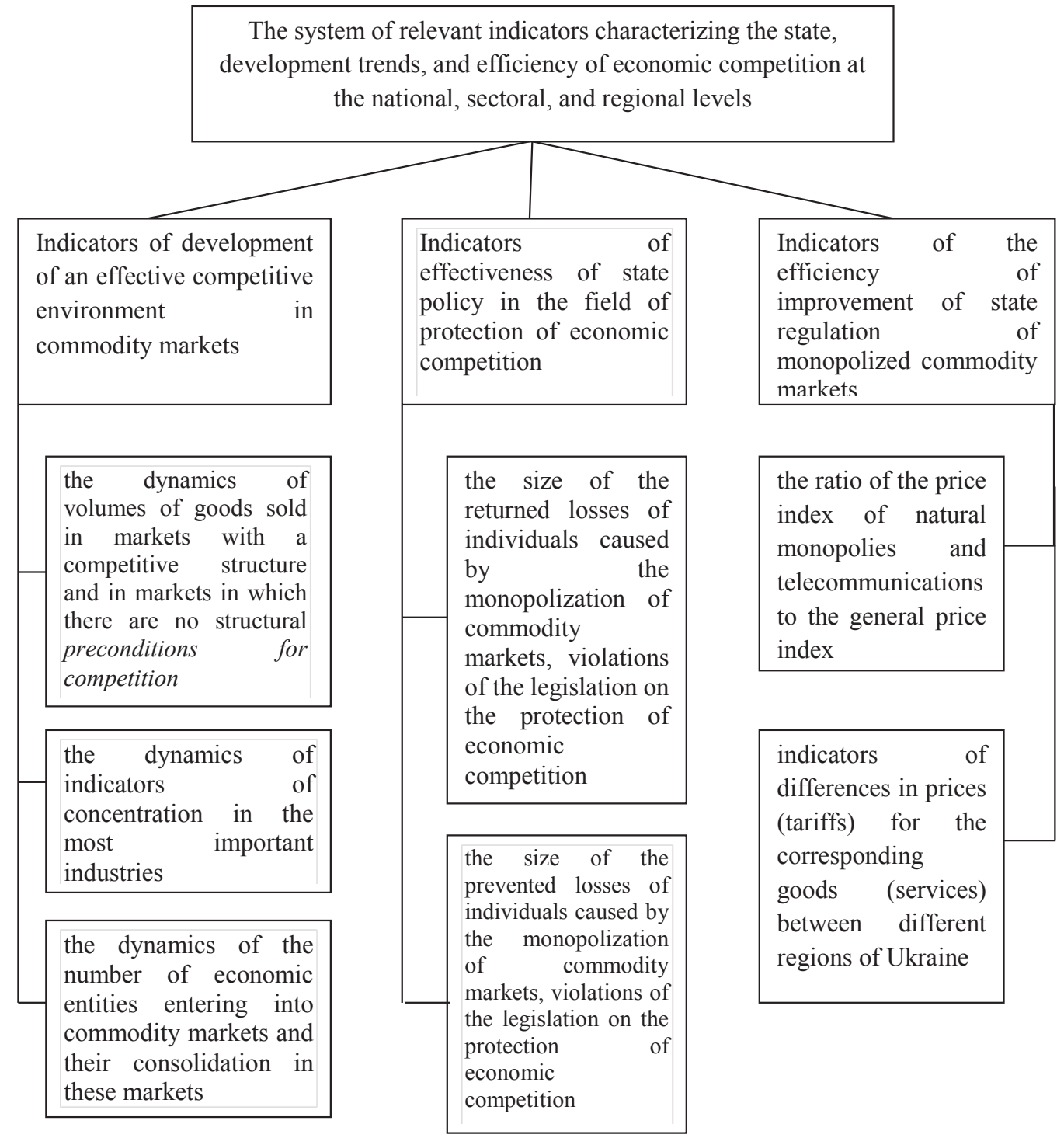

Figure 1. The system of indicators characterizing the state, development trends, and efficiency of economic competition at different levels 


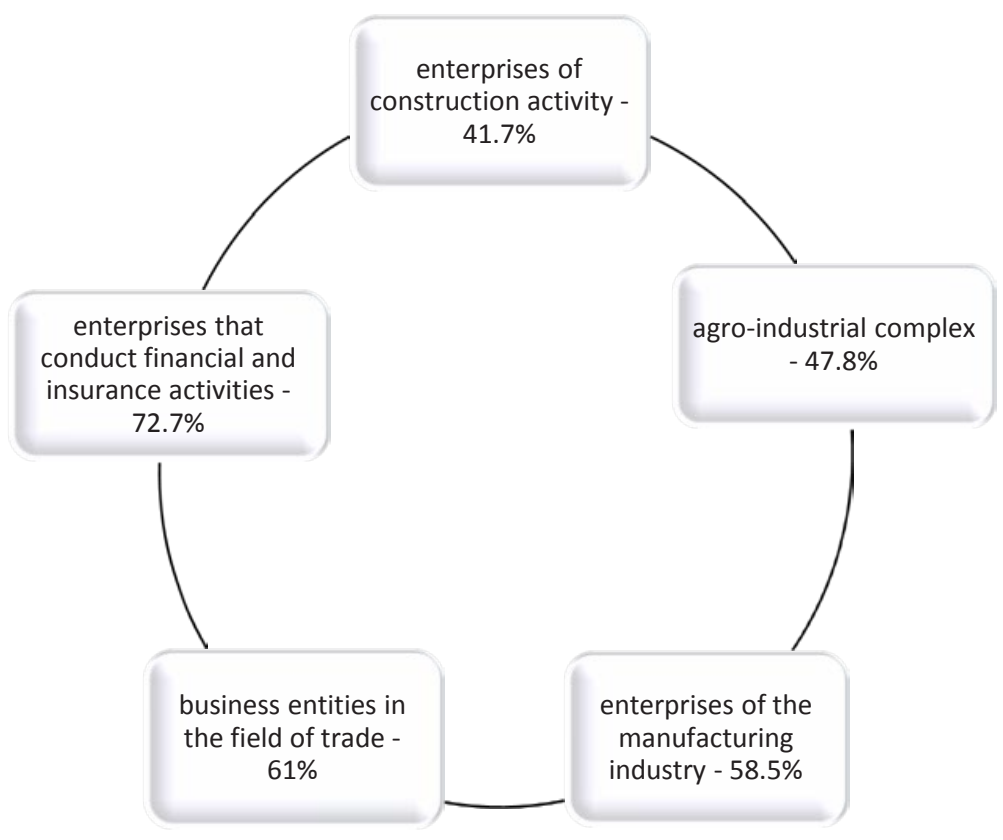

Figure 2. Areas of the national economy with high levels of internal competition

The AMCU has formed a clear position, which is steadily adhering that the fine for anticompetitive violations must exceed the illegally obtained profit and have a deterrent effect, while not removing the business entity from the market or depriving it of the ability to compete. Characterized by economic competition, certain indicators are shown in Figure 1.

In the context of various industries in 2017, the high level of internal competition have enterprises financial and insurance activities $-72.7 \%$; business entities in the field of trade $-61 \%$; enterprises of the manufacturing industry - 58.5\%; agro-industrial complex - 47.8\%; enterprises of construction activity - 41.7\% (Annual report, 2018).

Figure 2 illustrates the distribution of highly competitive markets in the national economy in 2017. Thus, highly competitive national markets are markets for financial and insurance services, trade, enterprises producing goods, agricultural products, construction works. By the enterprises of foreign countries in 2017, the highest level of competition is inherent in enterprises: mechanical engineering - 85.7\%; financial and insurance activities - 42.9\%; Mining and Metallurgical Complex (MMC) and transport - 33.3\%.

Figure 3 illustrates the level of competition from overseas companies. So, highly competitive are machine building, financial and insurance markets, MMC and transport (Bublyk, Koval, \& Redkva, 2017).

The analysis of the main results of the influence of state regulation in the field of economic competition in 2017 will make it possible to distinguish the main tendencies in the development of the competitive environment and to take into account them when forming the Strategy of Economic Development of Ukraine.

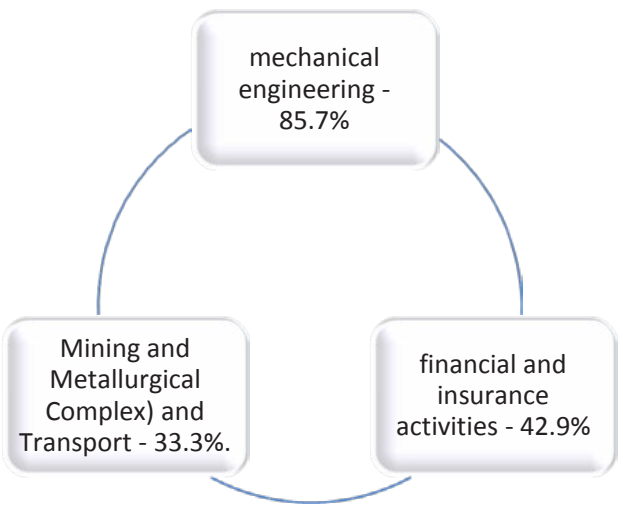

Figure 3. The level of competition in the national economy from foreign companies

The following features are characteristic of Ukraine's competitive relations at this stage of economic development: decrease in the total number of respondents in Ukraine experiencing competition from domestic enterprises; tangible structural changes in the distribution of the competitive environment; slowing down the development of inflationary processes; gradual restoration of economic activity; aggravation of the struggle for the consumer; revival of internal competition (Koval, 2017).

Therefore, nowadays in Ukraine, the tasks connected with the increase of efficiency of activity of state authorities in the sphere of protection and competition development in the domestic commodity markets are becoming more and more important, which resulted in the approval by the Cabinet of Ministers of Ukraine of the Concept of the National Competition Program for 2014-2024. There are three possible options for solving 
the problem of improving the efficiency of public authorities in the field of protection and development of competition.

The first option involves structural demonopolization, in particular, associated with changing ownership relations. For Ukraine, such an option is unlikely because 90 per cent of enterprises in the state have private ownership and grinding enterprises can lead to a decrease in their competitiveness in the foreign market.

The second option involves further liberalization of access of foreign business entities to the domestic market. However, with limited resources from domestic commodity producers, the emergence of an even greater number of foreign business entities will lead to negative consequences for the domestic economy, the social sphere, and national security.

The third option involves the state, represented by the authorized bodies of a complex of measures aimed at the development of competition, its protection, and restriction of monopoly. This option is the most suitable for Ukraine.

Considering that the Association Agreement between Ukraine, on the one hand, and the European Union, the European Atomic Energy Community and their member states, on the other hand, as of 27.06.2014, has launched the alignment of the Ukrainian legislation with the EU legal acts. This agreement allows Ukrainian enterprises to receive stable and predictable privileged access to the largest single market in the world with more than 500 million consumers, while EU companies can benefit from easy access to the Ukrainian market and establish new relationships with suppliers and partners. There are certain economic assessments on the formation of a competitive environment reform in Ukraine (on a scale from zero to 100, where 100 is the optimal situation). Thus, the assessment of the goods market in Ukraine, according to The Global Competitiveness Report 2018, is 55.3 points, the best is 73 (Singapore); the assessment of the labour market in Ukraine is 59.5, the best is 66 (USA); Estimation of the dynamics of business activity in Ukraine is 55.3 and the best is 86 (USA); the assessment of Ukraine's innovative capacity is 39.0, and the best is 58 (Germany) (Global Competitiveness Report, 2018).

Therefore, the priority directions of the implementation of competition policy in Ukraine are: harmonization of industrial, structural, innovation, investment, consumer protection policy with competitive state policy, promotion of effective competition on the basis of innovation model of economic development; increasing the competitiveness of the national economy in the domestic and foreign markets; reduction of administrative barriers to entering and leaving the commodity market; equal access of all business entities to all types of resources and information; formation of an atmosphere of mutual trust between state institutions and economic entities; development of the infrastructure of commodity markets and the application of modern instruments for regulating the activities of natural monopolies; taking into account the praxis factor in optimizing the activities of executive bodies and local self-government bodies; strengthening the role of monitoring on the state of economic competition at the national, sectoral and regional levels; harmonization of legislation on the protection of economic competition with European legislation in the relevant field.

\section{Conclusion}

The analysis of the general theoretical and real state of government regulation of economic competition in Ukraine shows that the national economy needs continuous improvement of the forms and means of state regulatory influence on the competition relations. Also, it needs the search for criteria for establishing the boundaries of state-legal interference in the sphere of competition and solving the key issue of development of the domestic competition law, which is associated with the definition of competition as a means of building a highly efficient economy.

State regulation of the competitive environment is a necessary tool for achieving a balance between public and private interests.

The main components of the state regulation of economic competition are legal regulation; granting of permits for economic competition and concerted actions; control over the state of the competitive environment; application to violators of sanctions. These components make it possible to create a certain mechanism for regulating economic competition in Ukraine.

The state mechanism of regulation of economic competition is a combination of legal and economic, organizational, within the limits of the law, the state's influence on the structure of the market and the economic behaviour of its entities, which enable an efficient allocation of resources (both public and private) and, as a consequence, the maximization of national well-being.

Prospects for further research are related to the definition of factors that influence the transformation of mechanisms of state influence on the competitive environment. In addition, they are based on the analysis of the main results of the influence of state regulation in the field of economic competition in 2017 and to consider them when forming the Strategy of Economic Development of Ukraine.

The diversity and ambiguity of approaches to economic competition in modern conditions create the need to deepen theoretical research of competition as a necessary and important element of the modern economy. 
Vol. 4, No. 4, 2018

\section{References:}

Annual report (2018). Antimonopoly Committee. Retrieved from: http://www.amc.gov.ua

Ansoff, I. (2001). Strategic Management . St. Petersburg: Terra. (in Russian)

Azoyev, G. L. (1996). Competition: analysis, strategy and practice. Moscow: Center for Economics and Marketing. (in Russian)

Bublyk, M., Koval, V. \& Redkva, O. (2017). Analysis impact of the structural competition preconditions for ensuring economic security of the machine building complex. Marketing and Management of Innovations, 4, 229-240. doi: 10.21272/mmi.2017.4-20 (in Ukrainian)

Global Competitiveness Report (2018). World Economic Forum. Retrieved from: https://www.weforum.org/ reports/the-global-competitveness-report-2018 (in Ukrainian)

Korchak, N. M. (2014). State regulation of competition relations in Ukraine (economic-legal aspect). Kiev : National Academy of Public Prosecutor of Ukraine. (in Ukrainian)

Koval, V. (2017). Competitive policy and regulation of oligopolistic markets with network effect. Wspótczesne Problemy Zarządzania, 11, 143-162.

Law of Ukraine on amendments to some laws of Ukraine on protection of economic competition and improvement of control procedures for concentration of economic entities № 2195-VIII. (2017). Vidomosti Verkhovnoyi Rady Ukrayiny, 1, 2. (in Ukrainian)

Law of Ukraine on protection of economic competition № 2210-III (2001). Vidomosti Verkhovnoyi Rady Ukrayiny, 12, 64. (in Ukrainian)

Law of Ukraine on sanctions № 1644-VII. (2014) Vidomosti Verkhovnoyi Rady Ukrayiny, 40, 2018. (in Ukrainian)

Law of Ukraine on government aid for business entities № 1555-VII. (2014, July 1). Vidomosti Verkhovnoyi Rady Ukrayiny, 34, 1173 (in Ukrainian).

Maslak, O. I., Kvyatkovskaya, L. A. \& Kulinichev, P. K. (2014). Competition: its essence and features in the conditions of globalization. Technological Audit And Production Reserves, 3(3), 57-61. (in Ukrainian)

Osinskaya, O. V. (2009). Theoretical concepts of social market economy. Scientific bulletin of UNFU, 19(7), 186-192. (in Ukrainian)

Porter, M. (1993). International Competition. Moscow: International relationship. (in Russian)

Rosetska, Yu. B. (2008). Institutional Principles of Development of Competitive Relations in the Economy of Ukraine. Odessa: ODEU. (in Ukrainian)

Schumpeter, J. A. (1982). Theory of Economic Development: An Investigation of Enterprise Profit, Capital, Credit, percent and the cycle of conjuncture. Moscow: Progress. (in Russian)

Shishka, R. B. \& Dzhumageldiev, G. D. (2015). State regulatory influence on the competition relations in Ukraine. Legal Bulletin. Air and Space Law, 1, 181-183. (in Ukrainian)

Smith, A. (2001). Goodwill of Nations. Research on the nature and causes of the welfare of nations. Kiev: Port-Royal. (in Ukrainian)

The order of the Cabinet of Ministers of Ukraine on approving the concept of a nationwide program for the development of competition for 2014-2024 № 690-p (2012). Retrieved from: http://zakon.rada.gov.ua/laws/ show/690-2012-p (in Ukrainian) 